\title{
CAMPUS WILDLIFE
}

by J. W. T. Spinks, President, University of Saskatchewan, Saskatoon

This description of wildlife on campus at e President's Residence in Saskatoon will troduce many of our readers for the first me to the Saskatchewan Natural History ciety's honorary president, Dr. J. W. T. inks. In the years that he has served as onorary president, Dr. Spinks' warm interest our projects has been much appreciated. ere he takes time from the busy round of tivities as President of the rapidly expand$g$ University of Saskatchewan to share his ersonal appreciation of wildlife with other aders of the Blue Jay.

One of the more pleasant aspects of he life of the President of tine Univerity of Saskatchewan is that he lives a very nice house situated at the p of a high bank overlooking the outh Saskatchewan River, near the 5th Street bridge in Saskatoon. There a rather large garden with many rees, including a very fine avenue of lue spruce leading down to the house. the garden is surrounded by a wire ence which serves to keep out at least me of the dogs and cats which might therwise stray in, and this encourges wild animals to come up from the iver bank to the garden. So we see abbits, squirrels, chipmunks, gophers, triped gophers, the occasional porcuine and weasel, and one evening ecently, a family of four skunks playhg together on a ledge of rock at the dge of the rock garden, just like kitens! We gave them a wide berth!

The animals are not an unmixed lessing. We don't mind the squirrels tripping the trees of cones, but we re not so happy when we find that he porcupine has chewed the bark off number of tree branches and that he $r$ the rabbit has developed an undeirable taste for young rose bushes wich get eaten right down to ground evel. And in the spring tulips seem to ake their fancy too. One rabbit took particular fancy to the pansies and vould eat them in a very entertaining ashion nipping off a stem well down rom the flower, chewing meditatively t the stem until only the flower remained just in front of the rabbit's ips, and then, plop, the flower would lisappear, just like a child sucking in pubble gum! Not so amusing when the rabbit does this at the rate of three per minute!

During the winter the various animal tracks in the fresh snow in the garden and in the driveway gave continuous pleasure, giving evidence that the animals were around even when one didn't see them.

The birds are a continuous and changing source of pleasure - robins, thrushes, woodpeckers, crows, canaries, orioles, starlings, catbirds, grosbeaks, mourning doves, etc., and even the occasional humming bird. The binoculars and bird books are always at hand even though we are not experts. Some winters we have had pheasants and partridges in the garden, and we have done our best to feed them. One winter a pheasant kept company with four partridges which would often spend the night on our lawn, almost buried in the snow. The pheasant would wait until one of the partridges had scraped a hole in the snow and then he would move in and settle down in the hole himself, head projecting in one direction, long tail lying on the snow in the other, apparently quite comfortable even at 40 below.

All in all, these casual but almost daily observations of wild life add greatly to the pleasure of living on campus.

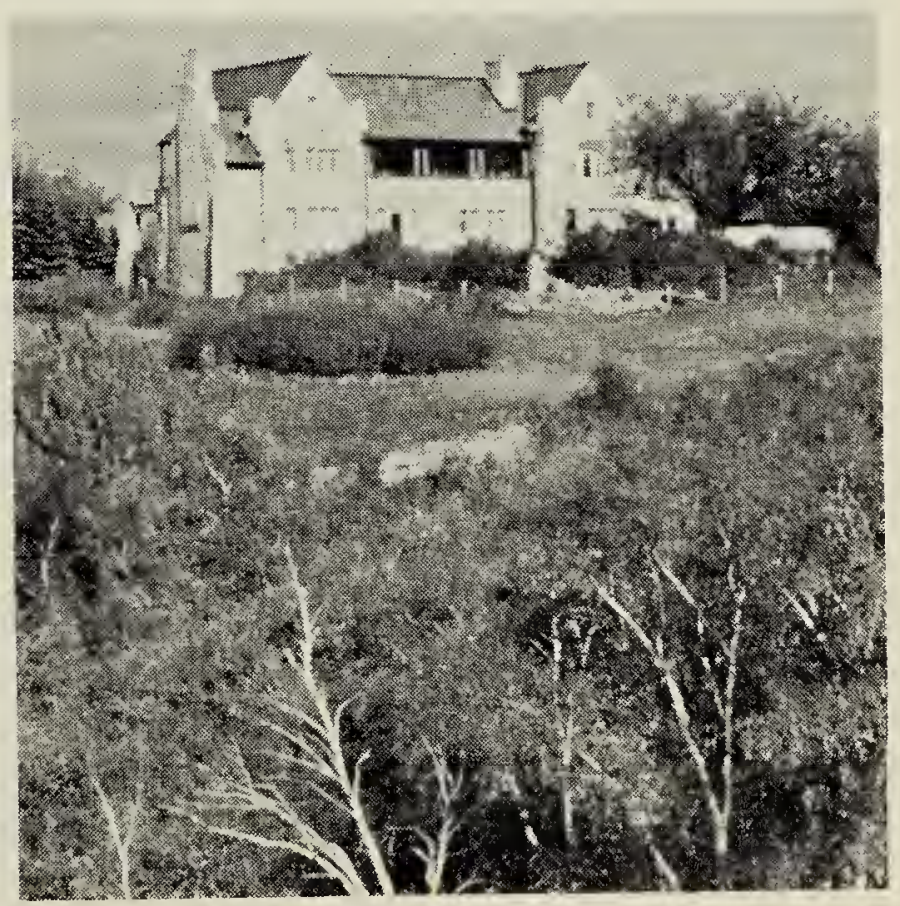

